\title{
Rama-The Epitome of Indian Ethics: Relevance to Modern Mental Health
}

\author{
Raveesh Bevinahalli Nanjegowda ${ }^{1}$, Ravindra Neelakantappa Munoli ${ }^{2}$
}

\begin{abstract}
India is known for its ancient traditions. From time immemorial, various faiths have flourished here. Ethics has its origin in its theology and philosophical thinking. Ethics is the core of all these multiple faith systems from the roots of Vedas, Upanishad's, and epics. The people's moral code is an indicator of their social and spiritual ways of life developed from these roots. They teach the true essence of human life is to live amidst worldly joy and sorrows. The epic Ramayana differentiates the term human value from social value. Ramayana means the journey of Rama. Though the central theme of the Ramayana revolves around the victory of good over evil, it is the righteousness and patience/tolerance of Rama in circumstances of adversity and felicity which colors the epic. Rama sacrificed all his pleasures for the welfare of his subjects upholding the true dharma. Translators have failed to find an exact equivalent English word for dharma. It is often said to be a duty and does not equate with religion. The three goals of human life as per Indian culture are artha (prosperity), kāma (desire), and dharma (righteous living); the fourth, which is the most important and ultimate goal of life, is moksha. The two essential aspects of Indian culture by which life goals are achieved are values and holism. Values refer to moral, spiritual, and ethical values, and holism means oneness or unity. Many dynasties, kings, and kingdoms ruled India. But Rama is considered the "Purushottama" or "Maryada Purusha" for his uncompromising and untiring binding with the core Indian values and ethics. This paper tries to reveal these much-needed ethical values in modern human life where such ethics are eroding.

Keywords: Indian ethics, Mental health, Rama, Ramayana.

Indian Journal of Private Psychiatry (2021): 10.5005/jp-journals-10067-0093
\end{abstract}

\section{INTRODUCTION}

India is one of the oldest civilizations following its ancient teachings in the technologically driven modern world. The ancient education system of India was very prosperous and value-based. These teachings reflect on ethics, values, morals, and psychological issues in day-to-day life. Indian scholars have shown that philosophy, religion, and medicine belonged together in ancient India and captured the Indian worldview. ${ }^{1}$ Unfortunately, the wisdom, richness, wholeness, and intense practicability of ancient Indian literature applicable during all periods of life needs more professional attention. ${ }^{2}$ The relevance of this ancient knowledge which is required to be made aware to our patients has been quoted with the example of Jambavantha making Hanuman realize his hidden potentials before going to Lanka in the epic of Ramayana. ${ }^{3}$ Ramayana and Mahabharata are two great epics that every Indian has heard or read. These epics did have a significant effect that shaped society at that time and continue to do so. Bhagavad Gita, part of the Mahabharata, is often considered one of the first psychological teachings, and many works of literature have been published regarding the same. ${ }^{4}$ However, in recent times, Ramayana, which is much older than Mahabharata, has kindled little interest by mental health professionals, even though it has many life lessons relevant to modern mental health practice. In south Asia, Ramayana finds its place in the most valued oral and literary texts, passed from generation to generation for ages. It is in poetry form and reflects the ethos of Indian culture and way of life. Penned by Maharshi Valmiki in Sanskrit, Ramayana has been translated into all Indian languages and many foreign languages. Millions have read it and revere it as scripture. In Indian families, it has been passed on from elders to their children that Rama is considered the one every man should thrive on being. His character is defined by upholding and fulfilling dharma, bravery, and courage, caring for
${ }^{1}$ Department of Psychiatry, Mysore Medical College and Research Institute, Mysuru, Karnataka, India

${ }^{2}$ Department of Psychiatry, Kasturba Medical College, Manipal Academy of Higher Education, Manipal, Karnataka, India

Corresponding Author: Raveesh Bevinahalli Nanjegowda, Department of Psychiatry, Mysore Medical College and Research Institute, Mysuru, Karnataka, India, Phone: +91 9980138016, e-mail: raveesh6@yahoo.com

How to cite this article: Nanjegowda RB, Munoli RN. Rama-The Epitome of Indian Ethics: Relevance to Modern Mental Health. Ind J Priv Psychiatry 2021;15(2):108-111.

Source of support: Nil

Conflict of interest: None

his family, and keeping his subjects happy. All this is because of Rama's ethics during his lifetime, even when significant challenges were encountered. Rama is a symbol of Indian culture irrespective of religion, region, caste, or language. Ramayana upholds the principle and good relationships, respects elders, loves for younger and has the foundation of family structure.

Colonialism brought in a dominant British flavor to Indian psychiatry, and it focused on increasing the mental hospital establishments as per the demand. ${ }^{5}$ Therefore, ancient knowledge of psychiatry in India is essential to understanding the actual perspective and laying a solid foundation for the future. ${ }^{6}$

\section{Relevance to Modern India}

Many aspects of Indian culture, rituals, practices, norms of living, art, and politics can be understood in the background of Ramayana. After independence, the nation has become the largest democratic country with its' own constitution. The Indian Constitution is unique 
in its content and spirit, keeping its ancient wisdom, and emerging modern challenges. The preamble to the constitution emphasizes the sovereign, socialist, secular, democratic, and republic character that confirms justice, liberty, equality, and fraternity to its citizens.

The framers of the Indian Constitution were great visionaries and had practiced values in their life, discharging societal and national obligations. They had followed noble ideals that inspired our national struggle towards freedom and the need to protect the country and promote harmony and secularism. Also, to preserve the rich heritage of the composite Indian culture. Every citizen was practicing these essential qualities and inherent values. They were first nurtured in the home traditionally and were subsequently supplemented by education in schools and colleges. These were an integral part of the way of life in India, and it was considered that aberrations in the practice of these would not be acceptable to society. The duties are spelled out in the preamble of the constitution that contains the ideals and aspirations of the people of India and the dedication of the constitution for fulfilling such objectives and aspirations. ${ }^{7}$ It becomes the onus of every citizen to respect and follow the hidden spirit of our constitution. However, "with the lapse of time, degradation of values, particularly values in public life became blatantly evident, and the nation felt the need to amend the Constitution and incorporate these values specifically as the Fundamental Duties of every citizen" (Justice Verma Committee Report). ${ }^{8}$ Hence, Article 51A, which constitutes Part IVA of the Constitution, reads as under: It shall be the duty of each citizen of India:

- "to abide by the Constitution and respect its ideals and institutions, the National Flag and the National Anthem."

- "to cherish and follow the noble ideals which inspired our national struggle for freedom."

- "to uphold and protect the sovereignty, unity, and integrity of India."

- "to defend the country and render national service when called upon to do so."

- "to promote harmony and the spirit of common brotherhood amongst all the people of India transcending religious, linguistic and regional or sectional diversities; to renounce practices derogatory to the dignity of women."

- "to value and preserve the rich heritage of our composite culture."

- "to protect and improve the natural environment including forests, lakes, rivers, and wildlife, and to have compassion for living creatures."

- "to develop the scientific temper, humanism and the spirit of inquiry and reform."

- "to safeguard public property and to abjure violence."

- "to strive towards excellence in all spheres of individual and collective activity so that the nation constantly rises to higher levels of endeavour and achievement."

In present-day competition based are frequently involved with individual rivalry to compete/achieve the destination professionally by hook or crook. Generally, students commit crimes in schools and colleges, or society due to a lack of ethical/moral values and their questionable commitments for their family, community, and nation. These can be hindrances in building a healthy society and a healthy government in the longer run. Materialism takes precedence over the goodness or competitiveness of the competitor. Education goals are not explicitly restricted to gathering knowledge in a subject or training the students to get jobs or do well in exams. The plans include training to enhance logical thinking, which could help the coming generations adjust to an adverse environment. Education in India must be entrusted with helping and molding students' character with moral values or ethics.

The importance of ethical values lies in that even the most dishonest person prefers to have an honest servant, partner, or friend.

\section{Rama as a Character}

Rama lived as a human being and faced the day-to-day situations and conflicts of life. Sri Rama is a perfect role model. Detaching oneself from fame, power, greed, desire, etc., Rama lived and enjoyed life. He entertained differences of opinion or dissent or oppositions and was kind and acted in just with them, which inspired people to face adversities in life circumstances. His serenity in success and tragedy is an excellent example to follow. Human life is often lost while chasing materialism, artha, and sensory pleasures known as the käma. It further emphasizes that the pursuits of artha and kāma must be very well within the frames of righteousness or dharma. Moksha or liberation is considered the final goal, and to attain this, artha and kāma are relinquished by strictly adhering to dharmic life. It further depicts that, for positive mental health, dharma can be a significant theme in productive and content life. Many conflicts in life can be resolved using this perspective. Patients in whom religion plays a pivotal role in their lives and whose mental health benefits from such practice should be encouraged to continue the same. Discussing religious issues may encourage them to explore different aspects of religion to increase their coping strategies. Similarly, patients with neurotic, stress-related, and adjustment problems in religious conflicts would also mandate a discussion on religious issues. Religion may have a protective effect against adverse mental health, or spiritual strain can produce harmful effects. ${ }^{9}$ However, Rama is considered beyond any religious connotation (Table 1). Salient qualities of Rama can be summarized as follows:

- Have faith and love for your work, not your position Rama wanted to be the king to serve his father. So, when his father gave him exile, Rama completed his duty.

- Rama remained wedded and staunchly loyal to his only wife, Sita. But, with his patience and practice, he stood firmly for his values and remained the greatest king in the history of India.

- Have an aim in life-Ramayana teaches us to have a good purpose in life. If we have a drive, we can stimulate our minds to do the work or fulfill our dream. Honesty should be part of life and way of life and should be reflected in a person's actions towards oneself, family, goals, society, culture, rituals, practices, and practices.

- The adverse situation in life-if we correctly take negative of life. These unfavorable situations make us strong.

- At the time of his exile, he pursues his potentials, self-fulfillment, personal growth, the peak experience of transcendence.

- Be careful of temptations and follow instructions, do not alter plans arbitrarily.

\section{Relevance to Mental Health}

Spiritual health is part of holistic health and can help a person change his lifestyle. Understanding the cultural context of the 
Table 1: Rama as character and relevance to modern mental health

\begin{tabular}{|c|c|c|}
\hline Rama's encounter & Situation & Context \\
\hline $\begin{array}{l}\text { Teacher, Vishwamitra's decision } \\
\text { about Ram's growth and learning }\end{array}$ & $\begin{array}{l}\text { Letting the person learn by experiences in an } \\
\text { unbiased way. }\end{array}$ & $\begin{array}{l}\text { Parents need to respect the independent thinking } \\
\text { and decision-making of their children. It can } \\
\text { be used in the context of the effects of parents' } \\
\text { over-involvement in a child's growth. }\end{array}$ \\
\hline Parasurama's challenge to Sri Ram & $\begin{array}{l}\text { Being calm in stressful situations, avoiding } \\
\text { spontaneous reactions to situations will help in } \\
\text { assessing problems. }\end{array}$ & How to face a crisis or stressful situation. \\
\hline $\begin{array}{l}\text { Sri Ram's obedience and acceptance } \\
\text { of exile }\end{array}$ & Choosing between own desire and elders' orders. & $\begin{array}{l}\text { We are respecting the decision of elders and } \\
\text { controlling one's desires. }\end{array}$ \\
\hline $\begin{array}{l}\text { Sri Ram's low mood and Sugreeva's } \\
\text { advice }\end{array}$ & $\begin{array}{l}\text { Personal crisis and difficulty in decision-making } \\
\text { during the crisis. Personal issues interfere in } \\
\text { professional life also. }\end{array}$ & $\begin{array}{l}\text { We are accepting suggestions and persisting with } \\
\text { the goal. }\end{array}$ \\
\hline $\begin{array}{l}\text { Sri Ram gives Ravana a second } \\
\text { chance }\end{array}$ & $\begin{array}{l}\text { It can be considered as helping a person to } \\
\text { change. It can be viewed in the context of } \\
\text { helping to stop substance use. Therefore, we are } \\
\text { allowed to reform. }\end{array}$ & We are providing an opportunity to change. \\
\hline Sri Ram's victory over Ravana & Success when one persists with a clear goal. & $\begin{array}{l}\text { We involve ourselves in work, relationships despite } \\
\text { ups and downs. }\end{array}$ \\
\hline $\begin{array}{l}\text { Sri Ram's serenity in success and } \\
\text { tragedy }\end{array}$ & $\begin{array}{l}\text { The focus will be on the process. The outcome } \\
\text { can be success or loss. }\end{array}$ & $\begin{array}{l}\text { Acceptance of people and situations as they are will } \\
\text { not induce much discomfort. }\end{array}$ \\
\hline The concept of dharma & $\begin{array}{l}\text { We need to focus on the assigned role and } \\
\text { responsibility rather than the outcome. }\end{array}$ & $\begin{array}{l}\text { Can help students/employees/family } \\
\text { members to focus on their roles and responsibilities } \\
\text { rather than the outcomes. }\end{array}$ \\
\hline
\end{tabular}

person with a mental disorder is essential before diagnosing, interpreting, and managing any emotional problems. ${ }^{10}$ Mental health professionals often avoid discussing religious issues with their patients as it is susceptible. ${ }^{11}$ However, encouraging patients to understand their spiritual conflicts improves the therapeutic relationship and often be part of long-term psychological intervention. Jackob and Krishna suggest using anecdotes from the Ramayana in psychotherapy. The similarity of the issues faced by a patient to that of Ramayana can throw light on insight. They are potent examples that help in finding alternate modes of coping.

It can be used in patients with dysthymia, neurotic and stress-related disorders and problems, adjustment difficulties, personality problems, maladaptive coping styles, marital discord and relationship difficulties, bereavement, academic, occupational, and phase of life problems. Using such a strategy is not dependent on the diagnostic label but instead on the individual, their religious background, and conflicts (Table 2). The therapist would have to match die stories and themes depending on the similarity to the patient's situation. $^{12}$

\section{Life Lessons from Ramayana}

Many value-based lessons can be learned from Ramayana. Ramayana tells us about good characters like bravery, calm, honesty, brotherhood, sacrifice, kindness, loyalty, morality, nobility, and patience, which are illustrated by the life of Rama. It also tells us about the bad qualities, such as greed, moral degradation, callousness, impoliteness, hostility, cruelty, and dishonesty (Table 3). Along with these ideas, there are other important ones that can be appreciated that are described below:

- Effect of lousy association-It has lessons to protect oneself from the wrong company and teaches one to remain vigilant against malicious advice. Further, it emphasizes a person to stay
Table 2: Family support to Rama

\begin{tabular}{|c|c|c|}
\hline Character & Situation & Context \\
\hline $\begin{array}{l}\text { Kousalya's } \\
\text { response to } \\
\text { Sri Ram's exile }\end{array}$ & $\begin{array}{l}\text { Someone else's decision } \\
\text { will affect a person's life } \\
\text { and emotions. }\end{array}$ & $\begin{array}{l}\text { Acceptance of a loss will } \\
\text { let the person adjust to } \\
\text { the crisis. }\end{array}$ \\
\hline $\begin{array}{l}\text { Sita's response } \\
\text { to Sri Ram's } \\
\text { exile }\end{array}$ & $\begin{array}{l}\text { We consider a family } \\
\text { member's problem as } \\
\text { our problem and share } \\
\text { the responsibility for the } \\
\text { problem. }\end{array}$ & $\begin{array}{l}\text { Strong primary support } \\
\text { will help in overcoming } \\
\text { stressful situations. } \\
\text { In addition, it can be } \\
\text { used in marital/couples } \\
\text { therapy. }\end{array}$ \\
\hline $\begin{array}{l}\text { Lakshmana's } \\
\text { response to } \\
\text { Sri Ram's exile }\end{array}$ & $\begin{array}{l}\text { We are sharing the } \\
\text { responsibility and helping } \\
\text { the family member } \\
\text { under challenging times. }\end{array}$ & $\begin{array}{l}\text { A primary support } \\
\text { system will help in } \\
\text { reducing the severity of } \\
\text { the situation. }\end{array}$ \\
\hline $\begin{array}{l}\text { Bharatha's } \\
\text { response to } \\
\text { Sri Ram's exile }\end{array}$ & $\begin{array}{l}\text { Injustice and } \\
\text { responsibility to be } \\
\text { balanced. }\end{array}$ & $\begin{array}{l}\text { Conflict in the family: } \\
\text { when different family } \\
\text { members have conflicting } \\
\text { views/actions. }\end{array}$ \\
\hline
\end{tabular}

firm with thoughts and to avoid getting biased or influenced by others in the decision-making process. It suggests observing one's thoughts from a critical angle to evaluate one's thoughts, emotions, behaviors, and outcomes, especially decision-making.

- Sibling bonding and brotherhood_Laxman left all the comforts of the palace, for his brother-Ram. Disputes between siblings have been witnessed in all scriptures for ages, and Ramayana is a model for sibling harmony. Situations where Bharat ruled Ayodhya in the name of Rama, with Ram's footwear on the throne, are examples of honesty, respect, and brotherhood.

- Control on emotions-When individuals excessively go with their feelings. It can lead to destruction. For example, if Ravana could have control over his feelings for Sita, war could not have occurred. 
Table 3: Ramayana as a theme to modern mental health

\begin{tabular}{|c|c|c|}
\hline Character & Situation & Context \\
\hline King Dashrath's promise to Vishwamitra & $\begin{array}{l}\text { Deciding something impulsively and } \\
\text { emotionally. }\end{array}$ & $\begin{array}{l}\text { Impulsivity in decision-making and not contacting } \\
\text { the stakeholders who may be affected by decisions, } \\
\text { only to end up in multiple domains. E.g., in the } \\
\text { context of substance use, self-harm, relationship } \\
\text { problems. }\end{array}$ \\
\hline Bhageeratha and the Ganges & $\begin{array}{l}\text { They are persisting with efforts with } \\
\text { a belief of desired change. }\end{array}$ & $\begin{array}{l}\text { The goal may seem far, but goal-directed and } \\
\text { persistent efforts will help reach the destination, } \\
\text { despite obstacles. }\end{array}$ \\
\hline Ahalya's role & Mistakes, forgiveness, hope & It can be used in marital/couples therapy. \\
\hline Dashrath's retirement & Role transition/life cycle. & $\begin{array}{l}\text { We are preparing and handing over roles and } \\
\text { responsibilities of house and profession to the } \\
\text { successors for better outputs. }\end{array}$ \\
\hline $\begin{array}{l}\text { Manthara's manipulated narrative of the } \\
\text { situation to change Kaikey's thought process }\end{array}$ & $\begin{array}{l}\text { Individual desires supersede the } \\
\text { team's wishes. }\end{array}$ & $\begin{array}{l}\text { It can be used to stress the importance of adhering } \\
\text { to a family's or team's goal at home or the workplace } \\
\text { to ensure a healthy outcome. }\end{array}$ \\
\hline $\begin{array}{l}\text { Hanuman's feelings of incompetent and } \\
\text { Jambavan's advice }\end{array}$ & $\begin{array}{l}\text { Inability to assess oneself and one's } \\
\text { potential when stressed/depressed/ } \\
\text { anxious/low self-esteem. }\end{array}$ & $\begin{array}{l}\text { We need to be clear and conscious about our abilities } \\
\text { and potentials. It can be an example of cognitive } \\
\text { distortion in exam anxiety, low self-esteem. }\end{array}$ \\
\hline III effects of alcohol and Sugreeva & $\begin{array}{l}\text { Multipronged adverse outcomes } \\
\text { because of substance use. }\end{array}$ & It can be used in substance use disorders. \\
\hline $\begin{array}{l}\text { Role of the squirrel in building the bridge } \\
\text { to Lanka }\end{array}$ & $\begin{array}{l}\text { It is the effort that matters, no matter } \\
\text { small or big. }\end{array}$ & $\begin{array}{l}\text { In the family context, all family members will have a } \\
\text { role in maintaining a healthy family atmosphere, no } \\
\text { matter how small the part might be. }\end{array}$ \\
\hline
\end{tabular}

- Know your weaknesses and strength-If a person knows his weakness and strength, we can suppress our weaknesses and make the best use of our power.

- Arrogance-It means exaggerating one's importance, ability, and merit. Our arrogant blindness stops us from receiving the goodness of others. And lose our badness. Arrogance leads to loss of presence of mind.

\section{Conclusion}

The Indian ethical values have relevance in the past, present, and future. Ancient wisdom in the form of teachings helps a human develop inner peace (shanti) and happiness (sukha) through the belief that work is worship, duty is god/godly than whatever the obstacles are awaiting in life. The inner strength can aid in understanding and solving problems rationally, which will help in enjoying life despite all hurdles. There may be a need to transcend the barriers between religion and psychiatry to improve patients' mental health. This need not be viewed as just an epic; instead, Ramayana can act as a medium of education to address the significance of ethics and values like honesty, respect, self-assessment, rational decision-making, and the importance of family, society, and people with special needs, and ethos. Systematic research is a need for culturally oriented modules of nonpharmacological management of mental disorders. The Ramayana contains mental therapeutic wisdom. It will remain an epic that is timeless and will also have lessons for all ages in the future.

\section{ORCID}

Raveesh Bevinahalli Nanjegowda (1) https://orcid.org/0000-00032766-9997

Ravindra Neelakantappa Munoli (1) https://orcid.org/0000-00023419-2819

\section{References}

1. Inbadas $\mathrm{H}$. Indian philosophical foundations of spirituality at the end of life. Mortality 2018;23(4):320-333. DOI: 10.1080/ 13576275. 2017.1351936. Available from: http://www.tandfonline.com/loi/ cmrt20 [Accessed on May 10, 2021].

2. Shamasundar $C$. Relevance of ancient Indian wisdom to modern mental health-a few examples. Indian J Psychiatry 2008;50(2): 138-143. DOI: 10.4103/0019-5545.42404.

3. Gautam S, Jain N. A review on Indian culture and psychiatry. Indian J Psychiatry 2010;52(Suppl. 1):S309-S313. DOI: 10.4103/ 0019-5545.69259.

4. Hegde S. National seminar on Bhagavad Gita and mental health: conference proceedings. Asian J Psychiatry 2009;1:60. DOI: 10.1016/ j.ajp.2008.09.011. PMID: 23051000.

5. Mishra A, Mathai T, Ram D. History of psychiatry: an Indian perspective. Ind Psychiatry J 2018;27(1):21-26. DOI: 10.4103/ipj.ipj_69_16.

6. Gautam S. Mental health in ancient India and its relevance to modern psychiatry. Indian J Psychiatry 1999;41(1): 5-18. PMID: 21455347; PMCID: PMC2962283.

7. Pandey JN. Constitutional law of India. Central Law Agency; Allahabad; 1998.

8. Report of the committee on amendments to criminal law, 2013. New Delhi: PRS Legislative Research; 2013 [Accessed on May 9, 2021].

9. Today. Available from: https://www.gktoday.in/gk/influence-ofindian-culture-on-ethical-values/ [Accessed on May 10, 2021].

10. Bhide SR, Kurhade $C$, Jagannathan A, et al. Feasibility of using counseling techniques from Ramayana for managing negative emotions: an anecdotal review and analysis. Indian J Psychol Med 2021;XX:1-5. DOI: 10.1177/0253717620975300.

11. Jackob KS, Krishna SG. Ramayana and psychotherapy. Indian J Psychiatry 2003;45(4):200-204. PMID: 21206858; PMCID: PMC2952364.

12. Gaur SK, Gupta D. Ethical values in epics especially in Sunderkand of Ramcharit Manas. Int J Manage Inf Technol 2017;2(2):66-69. 